\title{
Building Addressable Libraries: The Use of a Mass Spectrometry Cleavable Linker for Monitoring Reactions on an Microelectrode Array.
}

\author{
Ceng Chen, ${ }^{a}$ Gabriella Nagy, ${ }^{a}$ Amy Walker, ${ }^{a}{ }^{a}$ Karl Maurer, ${ }^{b}$ Andy McShea, ${ }^{b}$ and \\ Kevin D. Moeller ${ }^{\mathrm{a}}$ \\ ${ }^{a}$ Department of Chemistry, Washington University, St. Louis, MO 63130 and ${ }^{b}$ CombiMatrix \\ Corporation, 6500 Harbour Heights Pkwy, Suite 301, Mukilteo, WA 98275 \\ moeller@wuchem.wustl.edu
}

\section{Supporting Information}

\section{Synthesis of Linker and Substrates}<smiles>COC(=O)c1ccc(CCO)cc1</smiles>

(3)

A solution of methyl 4-vinyl-benzoate $(5 \mathrm{~g}, 30.8 \mathrm{mmol})$ in dry THF $(30 \mathrm{~mL})$ was treated with $0.98 \mathrm{~mL} \mathrm{BH}_{3}-\mathrm{Me}_{2} \mathrm{~S}(0.78 \mathrm{~g} 10.3 \mathrm{mmol})$ at $0{ }^{\circ} \mathrm{C}$ and the reaction mixture was warmed at room temperature and stirred for $2 \mathrm{~h}$, after which time $20 \mathrm{~mL}$ water was added to dilute the solution. Then $3 \mathrm{M} \mathrm{NaOH}$ solution $(12 \mathrm{~mL})$ and $30 \%(\mathrm{w} / \mathrm{w})$ hydrogen peroxide solution $(20 \mathrm{~mL})$ was added sequentially to the reaction at $0{ }^{\circ} \mathrm{C}$. The mixture was allowed to stir another $2 \mathrm{~h}$ at room temperature and was extracted with $\mathrm{CHCl}_{2}(3 \times 25 \mathrm{~mL})$. The organic layer was dried with $\mathrm{Na}_{2} \mathrm{SO}_{4}$ and concentrated in vacuum. Chromatography afforded $3(4.3 \mathrm{~g}, 78 \%)$ as clear oil. ${ }^{1} \mathrm{HNMR}\left(\mathrm{CDCl}_{3} / 300\right.$ MHz) $\delta 8.00(\mathrm{~d}, J=8.4 \mathrm{~Hz}, 2 \mathrm{H}), 7.31(\mathrm{~d}, J=8.1 \mathrm{~Hz}, 2 \mathrm{H}), 3.91$ (s, 3H), 3.90 (t, $J=6.6$ $\mathrm{Hz}, 2 \mathrm{H}), 2.94(\mathrm{t}, J=6.6 \mathrm{~Hz}, 2 \mathrm{H}) ;{ }^{13} \mathrm{CNMR}\left(\mathrm{CDCl}_{3} / 75 \mathrm{MHz}\right) \delta 39.4,52.3,63.4,128.6$, 129.3, 130.1, 144.5, 167.3; IR (neat) $v_{\max } 3381,2953,1704,1611,1437,1287,1181$, $1115,1044,1019,834,763,706 \mathrm{~cm}^{-1}$; EI HRMS m/z 180.0785.

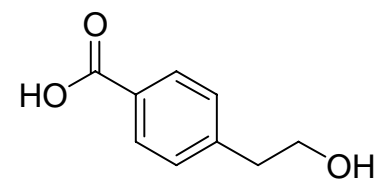

\section{(4)}

To a solution of $3(4.0 \mathrm{~g}, 22.2 \mathrm{mmol})$ in $\mathrm{MeOH}(20 \mathrm{~mL})$ was added $20 \mathrm{~mL}$ of $2 \mathrm{~N} \mathrm{NaOH}$. The mixture was refluxed for $3 \mathrm{~h}$ and then washed with $0.2 \mathrm{~N} \mathrm{HCl}(3 \times 20 \mathrm{~mL})$ and extracted with dichloromethane $(3 \times 20 \mathrm{~mL})$. The combined organic layers were dried over $\mathrm{MgSO}_{4}$, filtered and evaporated. Recrystallization with 1:1 hexanes- $\mathrm{CH}_{2} \mathrm{Cl}_{2}(25$ $\mathrm{mL}$ ) yielded 4 (3.0 g, 78\%). ${ }^{1} \mathrm{HNMR}(\mathrm{DMSO} / 300 \mathrm{MHz}) \delta 12.8(\mathrm{~s}, 1 \mathrm{H}), 7.83(\mathrm{~d}, J=8.1$ 
$\mathrm{Hz}, 2 \mathrm{H}), 7.32(\mathrm{~d}, J=8.1 \mathrm{~Hz}, 2 \mathrm{H}), 3.60$ (t, $J=6.9 \mathrm{~Hz}, 2 \mathrm{H}), 2.76(\mathrm{t}, J=6.9 \mathrm{~Hz}, 2 \mathrm{H})$;

${ }^{13} \mathrm{CNMR}(\mathrm{DMSO} / 75 \mathrm{MHz}) \delta 39.6,62.3,129.2,129.7,129.9,145.7,167.9$; IR (neat) $v_{\max }$ 3293, 2940, 2864, 1686, 1610, 1428, 1322, 1291, 1181, 1045, 934, 837, 741, $700 \mathrm{~cm}^{-1}$; LRFAB $\mathrm{m} / \mathrm{z}[\mathrm{M}+\mathrm{Li}]^{+} 173.1$.

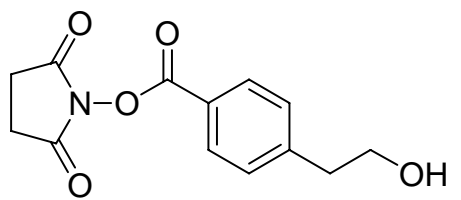

\section{(5)}

A mixture of $4(2.0 \mathrm{~g}, 11.5 \mathrm{mmol})$ and DCC (247 $\mathrm{mg}, 12.0 \mathrm{mmol})$ was stirred in THF $(25 \mathrm{~mL})$ under argon at $0^{\circ} \mathrm{C}$ until cloudy. N-hydroxysuccinimide $(138 \mathrm{mg}, 12.0 \mathrm{mmol})$ was added and the solution warmed to room temperature. After stirring overnight, the DCU was filtered and the filtrate was washed with brine and extracted with $\mathrm{CHCl}_{2}(3 \mathrm{x}$ $20 \mathrm{~mL}$ ). The organic layer was collected, dried with $\mathrm{Na}_{2} \mathrm{SO}_{4}$, and evaporated. Triturating with ether gave a white solid $(260 \mathrm{mg}, 86 \%)$. m.p. $113-116^{\circ} \mathrm{C}$; ${ }^{1} \mathrm{HNMR}$ $\left(\mathrm{CDCl}_{3} / 300 \mathrm{MHz}\right) \delta 8.07(\mathrm{~d}, J=8.4 \mathrm{~Hz}, 2 \mathrm{H}), 7.38(\mathrm{~d}, J=7.8 \mathrm{~Hz}, 2 \mathrm{H}), 3.90(\mathrm{t}, J=6.6$ $\mathrm{Hz}, 2 \mathrm{H}), 2.95(\mathrm{t}, J=6.6 \mathrm{~Hz}, 2 \mathrm{H}), 2.90(\mathrm{~s}, 4 \mathrm{H}) ;{ }^{13} \mathrm{CNMR}\left(\mathrm{CDCl}_{3} / 75 \mathrm{MHz}\right) \delta 25.8,39.4$, 63.1, 123.3, 129.7, 130.9, 147.1, 161.9, 169.6; IR (neat) $v_{\max } 3523,2942,1767,1736$, $1608,1417,1367,1205,1070,996,843,754,731,696,646 \mathrm{~cm}^{-1} ;$ HREI m/z $\left[\mathrm{M}-\mathrm{C}_{4} \mathrm{H}_{4} \mathrm{NO}_{2}\right]^{+} 149.0641$.

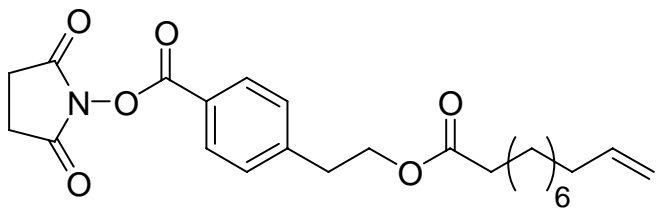

\section{(1)}

Under inert atmosphere, a solution of undecylenic acid (177 mg, $0.96 \mathrm{mmol})$ and DCC (1.1 eq) in dry DMF (5 mL) was stirred at $0{ }^{\circ} \mathrm{C}$. Compound 5 (230 mg, $\left.0.87 \mathrm{mmol}\right)$ was added to the solution and the resulting suspension warmed to room temperature and stirred overnight. After filtration, the filtrate was washed with brine and extracted with ethyl acetate $(3 \times 10 \mathrm{~mL})$. The combined organic solutions were evaporated and the crude product purified by silica gel chromatography. The pure product is a white solid. (110 mg, 27\%). ${ }^{1} \mathrm{HNMR}\left(\mathrm{CDCl}_{3} / 300 \mathrm{MHz}\right) \delta 8.07$ (d, $\left.J=8.4 \mathrm{~Hz}, 2 \mathrm{H}\right), 7.38$ (d, $J=7.8$ $\mathrm{Hz}, 2 \mathrm{H}), 5.81(\mathrm{~m}, 1 \mathrm{H}), 5.00(\mathrm{~m}, 2 \mathrm{H}), 4.32(\mathrm{t}, J=6.6 \mathrm{~Hz}, 2 \mathrm{H}), 3.02(\mathrm{t}, J=6.6 \mathrm{~Hz}, 2 \mathrm{H})$, $2.90(\mathrm{~s}, 4 \mathrm{H}), 2.26(\mathrm{t}, J=6.8 \mathrm{~Hz}, 2 \mathrm{H}), 2.03(\mathrm{~m}, 2 \mathrm{H}), 1.57(\mathrm{~m}, 4 \mathrm{H}), 1.36(\mathrm{~m}, 8 \mathrm{H})$; ${ }^{13} \mathrm{CNMR}\left(\mathrm{CDCl}_{3} / 75 \mathrm{MHz}\right) \delta 25.0,25.87,29.0,29.2,29.2,29.3,29.4,33.9,34.4,35.5$, $63.9,114.3,123.7,129.6,130.9,139.3,146.1,161.9,169.4,173.8$. IR (neat) $v_{\max } 2926$, 2854, 1736, 1725, 1608, 1417, 1367, 1257, 1205, 1070, 996, 843, 754, 731, 696, $646 \mathrm{~cm}^{-1}$; HREI $\mathrm{m} / \mathrm{z} \mathrm{M}^{+} 429.2148$. 


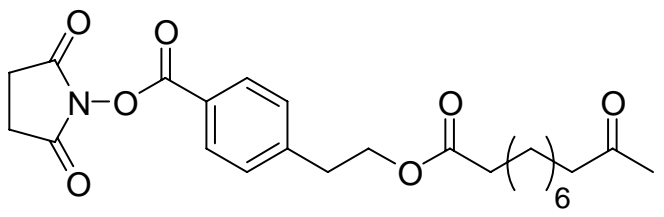

(2)

The synthesis of 2 was followed the same procedure used to synthesize 1. ${ }^{1} \mathrm{HNMR}$ $\left(\mathrm{CDCl}_{3} / 300 \mathrm{MHz}\right) \delta 8.06(\mathrm{~d}, J=8.2 \mathrm{~Hz}, 2 \mathrm{H}), 7.37(\mathrm{~d}, J=7.8 \mathrm{~Hz}, 2 \mathrm{H}), 4.30$ (t, $J=6.6$ $\mathrm{Hz}, 2 \mathrm{H}), 3.02$ (t, $J=6.8 \mathrm{~Hz}, 2 \mathrm{H}), 2.88(\mathrm{~s}, 4 \mathrm{H}), 2.23(\mathrm{t}, J=6.6 \mathrm{~Hz}, 2 \mathrm{H}), 2.13(\mathrm{~m}, 2 \mathrm{H})$, $2.08(\mathrm{~s}, 3 \mathrm{H}) 1.57(\mathrm{~m}, 4 \mathrm{H}), 1.36(\mathrm{~m}, 8 \mathrm{H}) ;{ }^{13} \mathrm{CNMR}\left(\mathrm{CDCl}_{3} / 75 \mathrm{MHz}\right) \delta 23.9,25.0$, 25.87, 29.0, 29.2, 29.2, 29.3, 29.4, 33.9, 34.4, 43.9, 52.2, 63.9, 123.7, 129.5, 130.9, 146.1, 161.8, 167.4, 173.8. IR (neat) $v_{\max } 3523,2942,1767,1736,1608,1417,1367$, 1205, 1070, 996, 843, 754, 731, 696, 646 $\mathrm{cm}^{-1}$; HREI m/z M 445.2083.

\section{General Procedure for Chip-based Wacker Oxidation}

\section{Agarose Coating on Chips}

The chips were spin coated with $4 \%$ agarose (DMF: $\mathrm{H}_{2} \mathrm{O}$ 19:1) at $2000 \mathrm{RPM}$ for 30 seconds.

\section{Substrate Loading on the Agarose Polymer}

A solution of $26 \mathrm{mg}$ substrate $1(0.06 \mathrm{mmol})$ in DMF $(100 \mu \mathrm{L})$ was added to a micro tube along with a solution of Vitamin $\mathrm{B}_{12}(2.8 \mathrm{mg})$ and $\mathrm{Me}_{4} \mathrm{NNO}_{3}(12 \mathrm{mg})$ in methanol $(1.5 \mathrm{~mL})$. The chip was incubated in the tube and then all of the electrodes were turned on at -2.4 volts relative to the Pt wire auxiliary electrode using a $0.5 \mathrm{sec}$ on and $0.1 \mathrm{sec}$ off pulse sequence for 300 cycles. After the reaction, the chip was washed with ethanol and water and let dry for next step.

\section{Anodic Oxidation}

To a mixture of $0.5 \mathrm{M} \mathrm{Et} t_{4}$ NOTf in acetonitrile and water (7:1) was added $\mathrm{Pd}(\mathrm{OAc})_{2}$ and tris(4-bromophenyl)amine $(1.39 \mathrm{mg})$. The amount of $\mathrm{Pd}(\mathrm{II})$ catalyst and confining reagent ethyl vinyl ether was varied for different experiments as outlined in the text. The chip prepared above was submerged in this solution and the electrodes pulsed at +2.4 volts relative to the Pt wire auxiliary electrode for 0.5 sec on and $0.1 \mathrm{sec}$ off. The reactions were conducted for 30,100 , or 300 cycles followed by washing with ethanol and let dry for TOF-SIMS analysis.

\section{Time-of-Flight Secondary Ion Mass Spectrometry}

Time of flight secondary ion mass spectra were obtained using a TOF-SIMS IV (ION-TOF Inc). The instrument consists of a loadlock, a preparation chamber and an analysis chamber, each separated by a gate valve. The preparation and analysis chambers were kept under ultra high vacuum $\left(10^{-9} \mathrm{mbar}\right)$. The primary ion beam was generated using a $\mathrm{Bi}^{+}$liquid metal ion gun. The primary ions were 
mass selected using their flight time between two deflection plates. The energy of primary ion beam was $25 \mathrm{keV}$.

The secondary ions generated were extracted into a time-of-flight mass spectrometer using an extraction voltage of $2000 \mathrm{~V}$. Before reaching the detector consisting of a multi channel plate/scintillator/photomultiplier tube, the secondary ions were reaccelerated to $10 \mathrm{keV}$ energy.

Analyzed sample areas were $\left(500 \times 500 \mathrm{~m}^{2}\right)$ on chip surface. Negative secondary ion mass spectra were collected for each sample. The primary ion dose during data acquisition was less than $10^{9}$ ions $/ \mathrm{cm}^{2}$, which corresponds to static SIMS. All the spectra were internally calibrated using $\mathrm{H}^{-}, \mathrm{C}^{-}, \mathrm{CH}^{-}, \mathrm{CH}_{2}^{-}, \mathrm{CH}_{3}^{-}$ and $\mathrm{C}_{2}^{-}$peaks. 